\title{
Cadmium nanoparticles citrullinate cytokeratins within lung epithelial cells: cadmium as a potential cause of citrullination in chronic obstructive pulmonary disease
}

This article was published in the following Dove Press journal:

International Journal of COPD

\author{
David Hutchinson, ${ }^{1,2}$ \\ Judith Müller, ${ }^{3}$ Joseph \\ E McCarthy, ${ }^{4}$ Yurii K \\ Gun'ko, ${ }^{4,5}$ Navin Kumar \\ Verma, ${ }^{6}$ Xuezhi Bi, ${ }^{7}$ Luisana \\ Di Cristo, ${ }^{8}$ Laura Kickham, ${ }^{8}$ \\ Dania Movia, ${ }^{8}$ Adriele \\ Prina-Mello, ${ }^{5,8}$ Yuri Volkov, 5,8 \\ 'Royal Cornwall Hospital NHS Trust, \\ Treliske, ${ }^{2}$ University of Exeter Medical \\ School Cornwall, UK; ${ }^{3}$ University \\ of Basel, Basel, Switzerland; ${ }^{4}$ School \\ of Chemistry, ${ }^{5}$ Advanced Materials \\ for BioEngineering Research \\ Centre (AMBER), Trinity College \\ Dublin, Dublin, Ireland; ' ${ }^{2}$ ee \\ Kong Chian School of Medicine, \\ Nanyang Technological University, \\ ${ }^{7}$ Bioprocessing Technology Institute, \\ A*STAR Graduate Academy, \\ Singapore; ${ }^{8}$ Department of Clinical \\ Medicine, School of Medicine, \\ Trinity College Dublin, Dublin, \\ Ireland; 'International Laboratory of \\ Magnetically Controlled Nanosystems \\ for Theranostics of Oncological \\ and Cardiovascular Diseases, ITMO \\ University, St. Petersburg, Russia
}

Correspondence: David Hutchinson Royal Cornwall Hospital NHS Trust, Treliske, Cornwall, TRI 3LJ, UK

Email david.hutchinson5@nhs.net

Yuri Volkov

Department of Clinical Medicine, School of Medicine, Trinity College Dublin, James's Street, Dublin 8, Ireland Emailyvolkov@tcd.ie
Objective: The objective of the study was to determine whether the cadmium-derived materials induce intracellular protein citrullination.

Methods: Human A549 lung epithelial cells were exposed to cadmium in soluble and nanoparticulate forms represented by cadmium chloride $\left(\mathrm{CdCl}_{2}\right)$ and cadmium oxide $(\mathrm{CdO})$, respectively, and their combinations with ultrafine carbon black (ufCB) produced by high temperature combustion, imitating cigarette burning. Protein citrullination in cell lysates was analyzed by Western immunoblotting and verified by immunofluorescent confocal microscopy. Target citrullinated proteins were identified by proteomic analysis.

Results: $\mathrm{CdO}$, ufCB and its combination with $\mathrm{CdCl}_{2}$ and $\mathrm{CdO}$ after high temperature combustion induced protein citrullination in cultured human lung epithelial cells, as detected by immunoblotting with anti-citrullinated protein antibody. Cytokeratins of type II $(1,2,5,6 \mathrm{~A}$, $6 \mathrm{~B}$ and 77$)$ and type $\mathrm{I}(9,10)$ were identified as major intracellular citrullination targets. Immunofluorescent staining confirmed the localization of citrullinated proteins both in the cytoplasm and cell nuclei.

Conclusion: Cadmium oxide nanoparticle exposure facilitated post-translational citrullination of proteins.

Keywords: cadmium, COPD, nanoparticles, cytokeratins, citrullination, autoimmunity, proteomics

\section{Introduction}

Chronic obstructive airways disease (COPD) is an inflammatory disorder of the airways and is an international health problem of great importance; between 1994 and 2010, 2.3 million deaths were attributed to COPD in the European Union and these deaths were associated with cigarette smoking. ${ }^{1}$ Important epidemiological work has identified that although smokers have an increased risk of COPD, this risk is greatly enhanced in individuals who have both smoked and had exposure to vapors, gases, dust and fumes (VGDF) in the workplace. ${ }^{2}$ Identifying a component or components of cigarette smoke and VGDF that induce COPD is likely to be of importance in the prevention and the understanding of the pathogenesis of COPD.

Cadmium $(\mathrm{Cd})$ is present as the nanoparticle cadmium oxide $(\mathrm{CdO})$ in cigarette smoke as the tobacco plant avidly takes up $\mathrm{Cd}$ from the soil via its roots and the metal subsequently accumulates in the tobacco leaf. ${ }^{3} \mathrm{Cd}$ concentrations in tobacco leaves 
range from 20 to $37 \mathrm{mg} / \mathrm{kg}$ (dry matter). ${ }^{4}$ The combustion of the tobacco leaf results in the generation of $\mathrm{CdO}$. The average cigarette contains about $2 \mu \mathrm{g} \mathrm{Cd}$ and $2 \%-10 \%$ of that dose is transferred by primary cigarette smoke. ${ }^{5}$ The amount of $\mathrm{Cd}$ is approximately two fold higher in smokers than in non-smokers and the biological half-life in the human body is about 30 years. ${ }^{6}$ Other major sources of exposure to $\mathrm{Cd}$ are volcanic activity, mining, fossil fuel combustion and the incineration of $\mathrm{Cd}$-containing batteries and plastics. Once absorbed, the cumulative levels of $\mathrm{Cd}$ in the body increase with age because of the lack of an active biochemical process for its elimination. ${ }^{7}$

Cadmium, therefore, can be inhaled into the lungs as a consequence of a myriad of environmental sources and is a very significant cause for concern with regard to ill health. ${ }^{8-10}$ Cadmium, in particular, is associated with an appreciable increased risk of COPD in smokers and ex-smokers ${ }^{11}$ and in occupationally exposed individuals. ${ }^{12-16}$ Animal studies have also convincingly demonstrated that an aerosol of $\mathrm{Cd}$ chloride induces emphysema. ${ }^{17}$

Other risk factors for COPD include occupational exposure to silica dust. ${ }^{18} \mathrm{We}$ have demonstrated previously that silica and carbon-derived nanoparticles cause intracellular citrullination of cytokeratins $7,8,18$ and plectins both in vitro and in vivo. ${ }^{19}$ This has possible implications for the understanding of the pathogenesis of COPD, and it is noteworthy that an autoantibody against cytokeratin 18 protein was found in $76.0 \%$ of COPD patients as opposed to $23.8 \%$ of control subjects $(p<0.001){ }^{20}$ This suggests that cytokeratins may be an important antigenic target in COPD. Accordingly, cigarette smoke has been observed to increase cytokeratin expression in lung epithelial cells. ${ }^{21}$

Citrullination, although primarily associated with autoimmune-mediated inflammatory diseases such as rheumatoid arthritis (RA) where citrulline is an essential constituent of antigenic determinants recognized by RAspecific autoantibodies, ${ }^{22}$ also occurs in COPD. Studies have observed citrullinated proteins in COPD lung samples or an autoimmune response to citrullinated proteins in the sera of COPD patients. ${ }^{23,24}$ Citrullination is a permanent post-translational modification that takes place after protein synthesis with conversion of peptidylarginine to peptidylcitrulline catalyzed by peptidylarginine deiminases. ${ }^{25}$ Given that citrullination occurs in the airways of smokers ${ }^{26}$ and that cadmium rather than silica is abundant in cigarette smoke, ${ }^{4}$ as a proof of concept study, we have tested whether cadmium has the potential to citrullinate intracellular proteins.

\section{Methods Significance of study}

The aim of the study was to test whether $\mathrm{Cd}$ has the potential to citrullinate intracellular proteins under conditions that reproduce conditions representative of the burning cigarette.

\section{Cell culture and treatments}

The experiments were carried out in human lung epithelial cell line A549 cultured in Dulbecco's Modified Eagle's Medium (Thermo Fisher Scientific, Waltham, MA, USA) supplemented with $10 \%$ fetal bovine serum, $5 \mu \mathrm{g} / \mathrm{mL}$ gentamicin and $1 \% \mathrm{~L}$-glutamine at $37^{\circ} \mathrm{C}$ in humidified atmosphere with $5 \% \mathrm{CO}_{2}$. The A549 cells were purchased commercially from ATCC. Cadmium chloride $\left(\mathrm{CdCl}_{2}\right)$ and $\mathrm{CdO}$ nanoparticles were used as soluble and nanoparticulate forms of cadmium, respectively. Ultrafine carbon black (ufCB) served as a control nanomaterial previously shown to induce protein citrullination. ${ }^{3}$ The combinations of $\mathrm{CdCl}_{2} / \mathrm{ufCB}$ and $\mathrm{CdO} / \mathrm{ufCB}$ after combustion at $\sim 500^{\circ} \mathrm{C}$ were used in the study as potentially imitating the more complex nanoparticulate substances present in the burning cigarettes. To eliminate the interference of acute toxic effects of cadmium-containing experimental compounds with the experimental results, cytotoxicity studies were initially carried out in a set of established high-content screening and analysis (HCSA) assays to determine toxic concentrations. The substances utilized in the experiments were then applied to the cells in sub-toxic concentrations of $1 \mu \mathrm{g} / \mathrm{mL}$ for $\mathrm{CdCl}_{2}$ and $\mathrm{CdO}$, and $10 \mu \mathrm{g} / \mathrm{mL}$ for ufCB. Cells were exposed to all the materials at $37^{\circ} \mathrm{C}$ for $24 \mathrm{~h}$.

\section{Western immunoblotting}

After the treatment cells were lysed in RIPA buffer (Santa Cruz Biotechnology, cat no sc-24948), lysates were sonicated for $15 \mathrm{~s}$ and centrifuged at $12,000 \times g$ for $20 \mathrm{~min}$ at $4^{\circ} \mathrm{C}$. After quantification with Pierce ${ }^{\circledR}$ BCA Protein Assay kit (Thermo Fisher Scientific, cat no 23225), aliquots of $50 \mu \mathrm{g}$ of proteins were mixed with SDS sample buffer, warmed at $95^{\circ} \mathrm{C}$ for $10 \mathrm{~min}$ and loaded on a 4\%-12\% gel for SDS-PAGE. After electrophoresis, proteins were transferred to polyvinylidene fluoride membranes (Immobilon-P; EMD Millipore, Billerica, MA, USA). Non-specific binding sites were blocked by incubating for $1 \mathrm{~h}$ at room temperature in 5\% dry milk in TBS-Tween 20. The blots were then exposed at $4^{\circ} \mathrm{C}$ overnight to anti-citrulline primary antibody (EMD Millipore, cat no 07-377) diluted in 5\% BSA in TBS-Tween 20. After washing, the blots were exposed for $1 \mathrm{~h}$ at room temperature to HRPconjugated anti-rabbit antibody (Cell Signaling Technology), 
and diluted 1:20,000 in blocking solution. Immunoreactivity was visualized with Lumina ${ }^{\mathrm{TM}}$ Forte Western HRP Substrate (EMD Millipore, cat no \#WBLUF0100).

\section{Immunoprecipitation}

After $24 \mathrm{~h}$ of treatment with Cd compounds, cells were lysed in RIPA buffer and then the amount of proteins were quantified as already described. Aliquots of $1 \mathrm{mg}$ of proteins were mixed with $3 \mu \mathrm{L}$ of anti-citrulline primary antibody (EMD Millipore, cat no 07-377), and then incubated with gentle rocking overnight at $4^{\circ} \mathrm{C}$. In total, $30 \mu \mathrm{L}$ of Protein A (SigmaAldrich Co., cat no P7786) was then added to the samples and incubated again with gentle rocking at $4^{\circ} \mathrm{C}$. After $3 \mathrm{~h}$, the samples were centrifuged for $30 \mathrm{~s}$ at $4^{\circ} \mathrm{C}$. The pellets were washed 3 times with $500 \mu \mathrm{L}$ of cell lysis buffer. The pellets were then resuspended in $20 \mu \mathrm{L}$ of SDS sample buffer (Thermo Fisher Scientific, cat no LC2676), heated at $95^{\circ} \mathrm{C}$ for $10 \mathrm{~min}$ and loaded on a $4 \%-12 \%$ gel for SDS-PAGE. After electrophoresis, the gel was rinsed 3 times for $5 \mathrm{~min}$ with deionized water to remove SDS and buffer salts. Finally, the gel was stained with enough Simply Blue ${ }^{\mathrm{TM}}$ SafeStain (Thermo Fisher Scientific, cat no LC6060) to cover the gel and incubated for $1 \mathrm{~h}$ at room temperature.

\section{Nano-liquid chromatography-electrospray ionization Orbitrap mass spectrometry/ mass spectrometry}

The major protein bands (3 bands for each lane) on Simply Blue SafeStain SDS-PAGE gel were excised and digested ingel with trypsin after reduction and alkylation. The resultant peptides were separated on a Waters nanoACQUITY Symmetry C18 trapping column $(180 \mu \mathrm{m} \times 20 \mathrm{~mm}, 5 \mu \mathrm{m})$ and separated online in nanoACQUITY UPLC BEH130 C18 column $(1.7 \mu \mathrm{m}, 75 \mu \mathrm{m} \times 200 \mathrm{~mm})$ (Waters) with a 60 min gradient of increasing acetonitrile concentration, containing $0.1 \%$ formic acid at a flow rate of $0.3 \mu \mathrm{L} / \mathrm{min}$. Mass spectrometry (MS) analysis was performed on LTQ-Orbitrap Elite ETD Mass Spectrometer (Thermo Fisher Scientific) using nanoelectrospray in positive ionization mode (CID) at $1.8 \mathrm{kV}$. The LTQ-Orbitrap Elite was operated in a top 15 peak data-dependent survey scans from 350 to $1,800 \mathrm{~m} / \mathrm{z}$ at a resolution of 120,000 . Top 15 tandem MS scans were acquired with normalized collision energy set to 35 for CID and single charged ions and repeated ion within $60 \mathrm{~s}$ excluded. Raw data files were subjected to database search using Peak Studio 7.5 software (Bioinformatics Solutions Inc., Waterloo, ON, Canada) against Uniprot human database with 20,196 entries. The peptide and fragmention mass tolerances used were \pm 10 ppm and $\pm 0.6 \mathrm{Da}$, respectively. The specified search parameters were trypsin digest with a maximum of 2 missed cleavages, carbamidomethylation of cysteine as fixed modification, oxidation of methionine, deamidation of asparagine and glutamine, and citrullinated arginine as variable modifications. Ten or more matching peptides (false discovery rate at $0.1 \%, \geq 2$ unique peptides) and at least one confidently identified arginine citrullinated peptide (PEAKS DB Scoring $-10 \lg P>25$ ) were required for a secure identity assignment.

\section{Immunostaining and laser scanning confocal microscopy}

A549 cells were seeded on sterile coverslips (diameter: $16 \mathrm{~mm}$ ) placed in 24-well plates at a cell density of $1 \times 104$ cells/well. After incubating for $24 \mathrm{~h}$ at $37^{\circ} \mathrm{C}$, cell cultures were exposed to the nanomaterials at the same concentrations tested in the Western blotting experiments. Cells were then washed with pre-warmed PBS twice and fixed for 10 min with $3.7 \%$ paraformaldehyde. Specimens were then permeabilized with $0.1 \%$ TritonX-100 for $5 \mathrm{~min}$. Following incubation in blocking buffer (1\% bovine serum albumin [BSA] and 10\% FBS) for $1 \mathrm{~h}$ at ambient temperature, specimens were extensively washed with PBS and stained for citrulline with rabbit polyclonal anti-citrulline antibody (ab100932; Abcam, Cambridge, UK) at a dilution equal to $1: 200$ in $0.05 \%$ BSA. Staining was performed overnight at $4^{\circ} \mathrm{C}$. Cells were then washed with PBS and incubated with the anti-rabbit FITC-conjugated secondary antibody (1:500) (Thermo Fisher Scientific) for $24 \mathrm{~h}$ at $4^{\circ} \mathrm{C}$. During this step, the following cell compartments were also stained: nuclei with Hoechst $33342(1: 1,000)$ and F-actin with rhodamine phalloidin (1:200) (both purchased from Thermo Fisher Scientific). After washing with PBS, specimens were mounted in transparent mounting medium (Vectashield; Vector Laboratories Inc., Burlingame, CA, USA) prior to laser scanning confocal microscopy analysis by a Zeiss LSM 510 Meta confocal microscope equipped with a Zeiss Zen software (Carl Zeiss Meditec AG, Jena, Germany). The appropriate controls (ie, untreated A549 cells stained only with Hoechst, rhodamine phalloidin and the secondary antibody) were also prepared.

\section{Results}

Cadmium compounds were cytotoxic to the A549 epithelial cells at concentrations above $5 \mu \mathrm{g} / \mathrm{mL}$ (HCSA data not shown). Based on the results of cytotoxicity measurements, 
all the materials utilized in the experiments were subsequently applied to the cells in sub-toxic concentrations as indicated in Methods, Cell culture and treatments section. $\mathrm{CdO}$, ufCB and its combination with $\mathrm{CdCl}_{2}$ and $\mathrm{CdO}$ after high temperature combustion were capable of inducing citrullination of proteins in cultured human lung epithelial cells of A549 cell line, as detected by Western immunoblotting (Figures 1 and S1). Citrullination was significantly enhanced where Cd compounds were used post-combustion with ufCB. This was especially pronounced with $\mathrm{CdCl}_{2}$ (Figures 1 and $\mathrm{S} 1$ ). Cellular proteins undergo post-translational citrullination via a peptidyl-arginine deiminase-dependent mechanism, as demonstrated in our previous studies. ${ }^{19}$ The majority of citrullinated proteins were represented by the bands corresponding to the molecular weights between 55 and $72 \mathrm{kDa}$, and several less abundant bands at the level of $\sim 25 \mathrm{kDa}$ and over $130 \mathrm{kDa}$ (Figure 2). Acidic cytokeratins of type I $(9,10)$ and basic/ neutral cytokeratins type II $(1,2,5,6 \mathrm{~A}, 6 \mathrm{~B}$ and 77$)$ were identified as predominant intracellular citrullination targets (Table S1). Immunofluorescent staining demonstrated that the citrullinated proteins were localized both in the cytoplasm
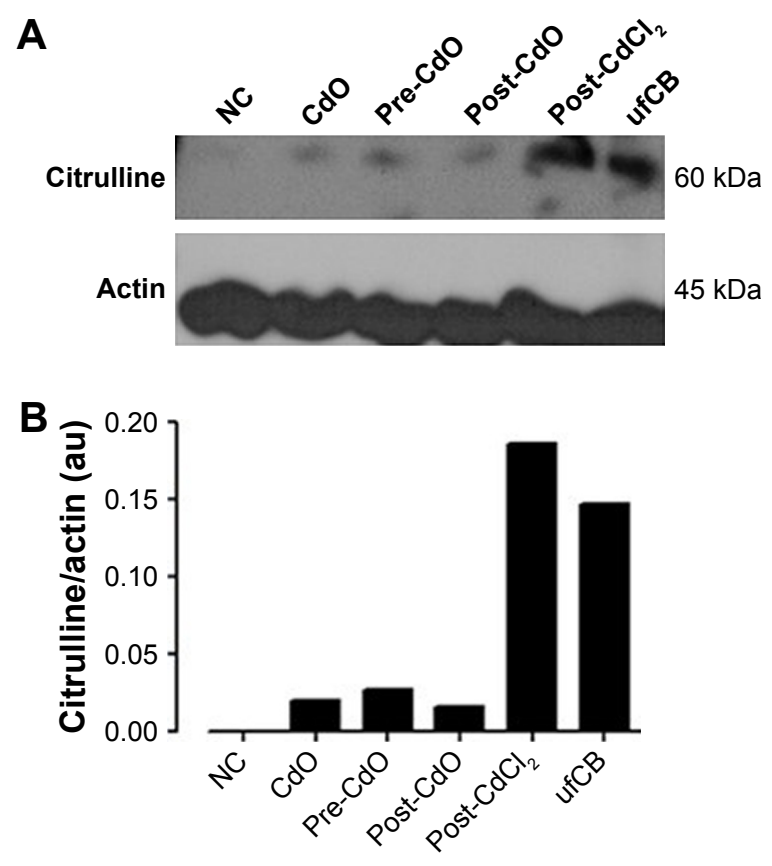

Figure I Detection of protein citrullination by Western immunoblot analysis. Notes: A549 cells were left untreated (NC) or exposed to sub-toxic concentrations of $\mathrm{Cd}$ compounds. After $24 \mathrm{~h}$ of treatment, protein citrullination was quantified by Western blotting. A representative blot is shown, with actin used for loading control (A). The quantification analysis of the same blot is shown. The experiment was performed twice with comparable results (B). Cd, cadmium; NC, no treatment; $\mathrm{CdO}$, treatment with $\mathrm{CdO}$ alone; Pre-CdO, exposure to $\mathrm{CdO}+$ ufCB precombustion; Post-CdO, exposure to $\mathrm{CdO}+$ ufCB post-combustion; Post- $\mathrm{CdCl}_{2}$, exposure to cadmium chloride + ufCB post-combustion; ufCB, treatment with ultrafine carbon black alone.

Abbreviations: NC, negative control; $\mathrm{CdO}$, cadmium oxide; $\mathrm{CdCl}_{2}$, cadmium chloridel; ufCB, ultrafine carbon black.

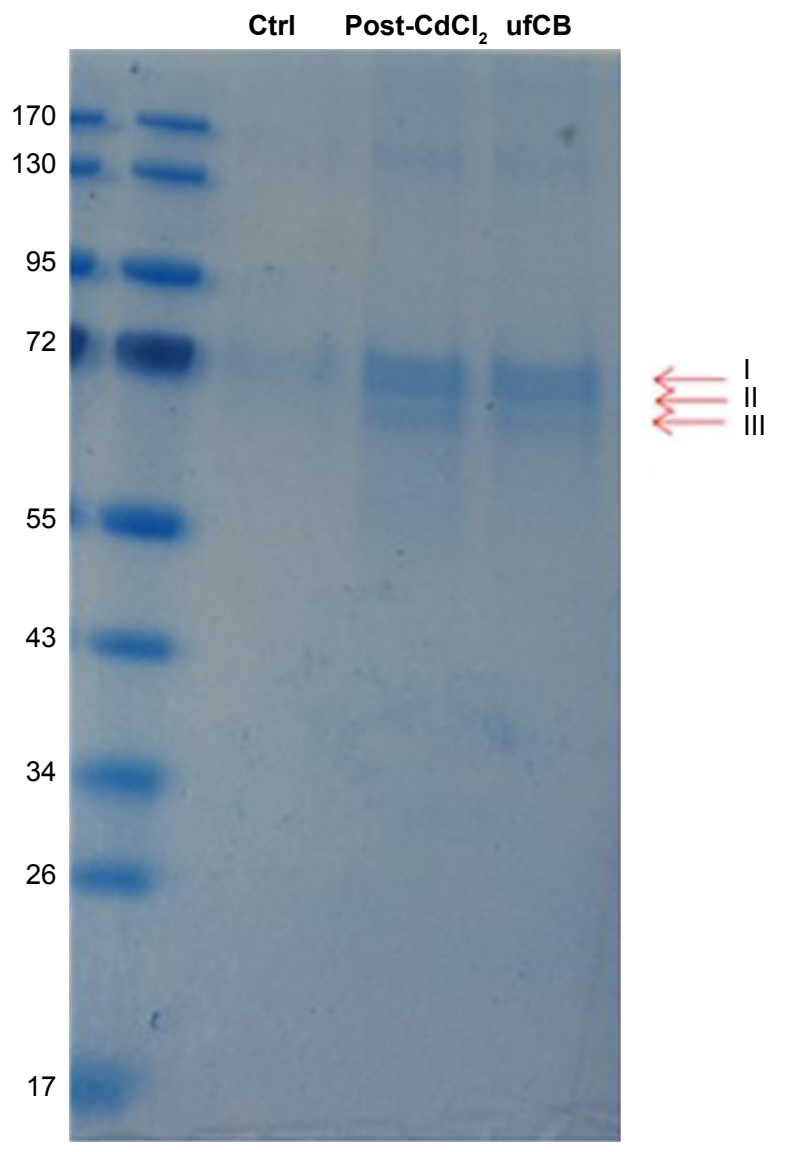

Figure 2 Immunoprecipitation of citrullinated proteins for proteomic analysis. Notes: $\mathrm{A} 549$ cells were left untreated ( $\mathrm{Ctrl}$ ), exposed to $\mathrm{CdCl}_{2} /$ ufCB post-combustion (Post- $\mathrm{CdCl}_{2}$ ) or ufCB for $24 \mathrm{~h}$ and lysed. Cell lysates were immunoprecipitated, resolved by SDS-PAGE and visualized by Simply Blue ${ }^{\text {TM }}$ SafeStain. Bands of interest, as indicated in the figure by arrows I, II and III, were excised and processed for nanoliquid chromatography-electrospray ionization.

Abbreviations: $\mathrm{Ctrl}$, control; $\mathrm{CdCl}_{2}$, cadmium chloridel; ufCB, ultrafine carbon black.

(distributed in a speckled pattern) and nuclei (as diffuse staining and discrete, more intense compact spots) of cells exposed to $\mathrm{Cd}$ nanoparticles, similarly to the distribution patterns observed in cells exposed to ufCB (Figure 3 ).

\section{Discussion}

This study has established for the first time that $\mathrm{Cd}$ in particulate form causes citrullination of intracellular cytokeratins 1 , 2, 5, 6A, 6B, 9, 10 and 77, belonging both to type I (acidic) and type II (neutral/basic) cytokeratin proteins. Intracellular distribution patterns of citrullinated proteins following $\mathrm{CdO}$ and ufCB exposure included both cytoplasmic and nuclear components, in concert with the recent findings suggesting the involvement of cytokeratins in nucleocytoplasmic transport and signaling. ${ }^{27}$ Of note, among the cytokeratins identified in the present study, keratins 6A, 6B, 10 and 77 possess nuclear localization sequence motifs. ${ }^{27}$ The identities of other citrullinated proteins with molecular weights 


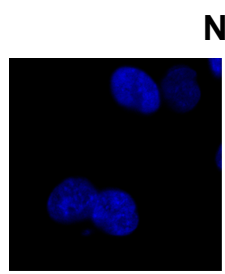

NC

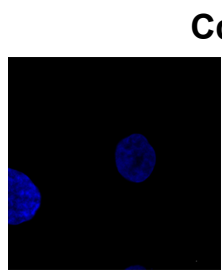

CdO

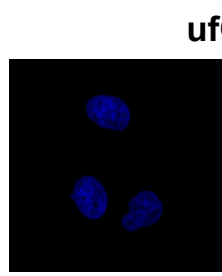

ufCB
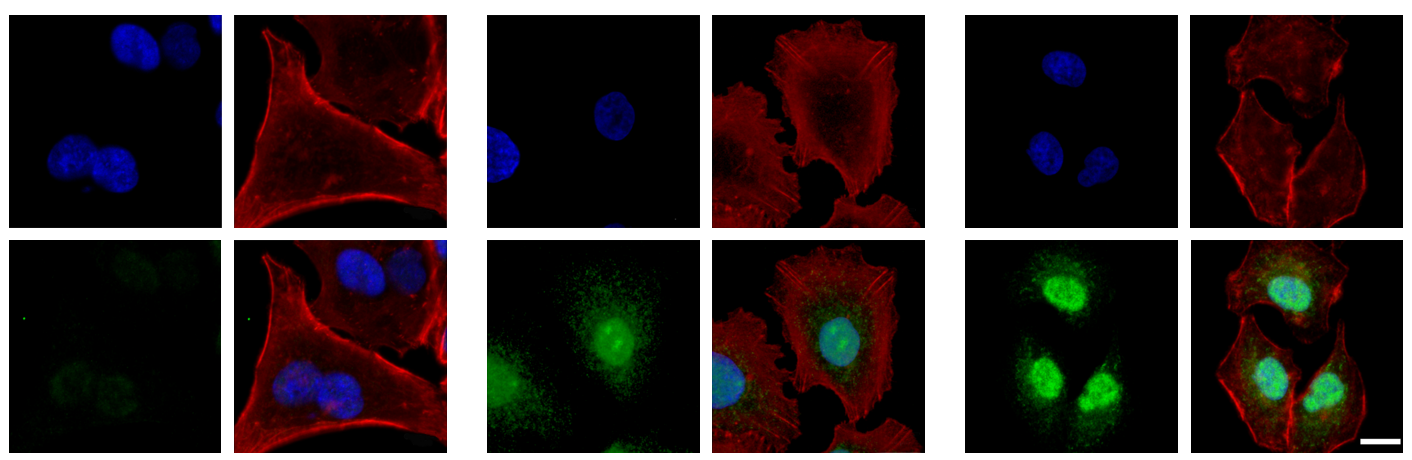

Figure 3 Immunofluorescent detection of protein citrullination in human lung epithelial cells A549.

Notes: NC, unexposed cells; CdO, cells exposed to nanoparticulate cadmium material; ufCB, cells exposed to ultrafine carbon black. Upper left panels, nuclei (blue); upper right panels, actin cytoskeleton (red); lower left panels, immunofluorescent staining for the presence of citrullinated proteins (green); lower right, merged staining panels. Scale bar, $10 \mu \mathrm{m}$.

Abbreviations: NC, negative control; $\mathrm{CdO}$, cadmium oxide; ufCB, ultrafine carbon black.

below $30 \mathrm{kDa}$ and over $130 \mathrm{kDa}$ detected in this study will require further investigations.

We have demonstrated previously that cytokeratins and plectins are the citrullination targets in A549 cells exposed to $\mathrm{SiO}_{2}$ and carbon-derived nanomaterials. ${ }^{19}$ However, $\mathrm{Cd}$ is an important component of cigarette smoke, whereas $\mathrm{SiO}_{2}$ is not. We have demonstrated here that $\mathrm{CdO}$ induces intracellular citrullination of cytokeratins. We suggest that citrullination is highly relevant to COPD as a consequence of the generation of potential neoantigens. Previously, an antibody response to native cytokeratin 18 protein has been observed in COPD, ${ }^{20}$ and it will be of interest to study whether there is an anticitrullinated protein (ACPA) response to the citrullinated cytokeratins reported here.

Certainly, heavy smoking COPD patients have been reported to have the highest prevalence of positive ACPA (7.4\%) as opposed to never smokers (2.4\%): OR 3.26, 95\% CI 0.85-12.6, $p=0.089$. Furthermore, COPD smokers had significantly higher levels of ACPAs than smokers without COPD. ${ }^{24}$ The prevalence of reported serum ACPA positivity in COPD has been reported in other studies to be between $7 \%$ and $17 \% .{ }^{28,29}$ However, serum antibody levels do not take into account local lung antibody production and the possibility that these antibodies are then sequestered as a result of complement fixation potentially generating local tissue damage. Indeed, abundant citrullination of proteins in the lung has been observed in lung cancer patients and correlated with the tissue expression of cytokeratin 7 . The authors suggested that citrullination may be helpful in distinguishing lung cancer from healthy tissue. ${ }^{30}$

It has been hypothesized that COPD may have an autoimmune component ${ }^{31}$ and further studies will be important in determining whether $\mathrm{Cd}$ inhalation can initiate an autoimmune process. Certainly, citrullination is central to the pathogenesis of the autoimmune disease $\mathrm{RA}^{22}$ and there are striking parallels between RA and COPD as they share similar environmental risk factors such as heavy smoking ${ }^{32}$ and occupational exposures to VGDF. ${ }^{33}$ A systematic review and meta-analysis demonstrated that both RA and COPD clustered together with a statistically significant increased risk of subsequent development of COPD among patients with RA independent of cigarette smoking. The pooled risk ratio of incident COPD in patients with RA versus control was 1.99 (95\% CI 1.61-2.45). ${ }^{34}$ Interestingly, there appears to be an emerging literature to suggest that Cd exposure is associated with RA development. ${ }^{35}$

Aside from the potential development of autoimmunity, citrullination is likely to be of importance in COPD development and or severity. For example, the citrullination of LL-37 (an important component of innate immunity) results in a 40 -fold reduction in its neutralization of the proinflammatory activity of lipopolysaccharide due to a marked decrease in its affinity for endotoxin as the introduction of citrulline significantly changes the structure and function of LL-37. ${ }^{36}$

Additionally, polymorphonuclear neutrophils release neutrophil extracellular traps (NETs), which express an abundance of neutrophil elastase. It has been demonstrated that COPD sputa are abundant in NETs and that the formation of NETs is associated with the generation of citrullinated histone H3. ${ }^{37}$ Recently, it has been demonstrated that cigarette smoke extract (CSE) is an important facilitator that triggered neutrophils to undergo NETosis in vitro. Furthermore, CSE-induced NETs were capable of driving plasmacytoid dendritic cell maturation and activation, thereby initiating a T-cell-mediated immune response. ${ }^{38}$

In view of the aforementioned details, we suggest that $\mathrm{Cd}$ exposure and subsequent protein citrullination is relevant 
to COPD pathogenesis and warrants further extensive investigation.

\section{Limitations}

A limitation of the study was that the effect of Cd was not measured over a prolonged period of time $(24 \mathrm{~h}$ in this study), and it is conceivable that other intracellular proteins could be upregulated and citrullinated by prolonged cellular exposure to $\mathrm{Cd}$. In keeping with this, chronic $\mathrm{Cd}$ exposure in vitro induces cancer cell characteristics in human lung cells over 20 weeks with an increased expression of the epithelial-to-mesenchymal transition marker protein vimentin. ${ }^{39}$ We have not investigated the mechanism by which $\mathrm{Cd}$ induces citrullination or whether the combination of both $\mathrm{Cd}$ and silica nanoparticles have an enhanced effect on citrullination. However, given that we observed that citrullination was significantly enhanced where $\mathrm{Cd}$ compounds were used post-combustion with ufCB, it is conceivable that a combination of both $\mathrm{Cd}$ and silica nanoparticles has an enhanced effect on citrullination.

This study utilized A549 cell, which is a transformed cell line. However, we feel that this cell line is representative of primary cell lines as A549 cells have been used as a model closely imitating type II alveolar cells for decades. ${ }^{40-42}$ We appreciate that it is a transformed cell line and understand potential limitations, but intentionally utilized it for the sake of consistency of experimental data in the studies performed on several types of cadmium compounds, different time points and exposure scenarios. Another consideration was the significant volumes of cell lysates required for the immunoprecipitation and protein sequencing studies, which would not have been achievable using the primary cells. Furthermore, in our earlier relevant study, the experimental results obtained in A549 cells were fully confirmed by longterm in vivo animal tests. ${ }^{19}$

\section{Clinical implications}

Molecules that inhibit citrullination may be of importance in the treatment of COPD. There are protein arginine deiminase (PAD) inhibitors in development. First- and second-generation PAD inhibitors have shown promise in preclinical studies with animal models of diseases where protein citrullination is known to be important. ${ }^{43} \mathrm{Cd}$ is a potent generator of superoxide within the cell. ${ }^{44}$ This is relevant to citrullination and the generation of neutrophil NETs as superoxide has been observed to citrullinate histone $\mathrm{H} 3$ with the subsequent development of neutrophil NETs. ${ }^{45}$ There are potential therapeutic agents that may negate $\mathrm{Cd}$-induced citrullination. For example, zinc has been observed to reduce the antioxidant burden in $\mathrm{COPD}^{46}$ and has been noted to reduce $\mathrm{Cd}$-induced superoxide concentrations ${ }^{44}$ and therefore may be of therapeutic relevance to $\mathrm{Cd}$-induced COPD patients. Additionally, $\mathrm{N}$-acetyl cysteine can reduce superoxide generation and has been demonstrated to result in decreased NET formation ${ }^{45}$ and therefore may also be of relevance to $\mathrm{Cd}$-induced COPD.

\section{Conclusion}

The clinical relevance of this study provides evidence for the first time that $\mathrm{Cd}$ is associated with intracellular citrullination. The proteins citrullinated were cytokeratins of type II $(1,2,5$, $6 \mathrm{~A}, 6 \mathrm{~B}$ and 77$)$ and type I $(9,10)$. Immunofluorescent staining confirmed the localization of citrullinated proteins both in the cytoplasm and cell nuclei. These data may be useful to help identify useful ACPAs relevant to COPD patients. Further studies to determine if citrullination of cytokeratins can contribute to airway inflammation and tissue remodeling will be of interest. Additionally, studies to determine if $\mathrm{Cd}$ exposure and subsequent citrullination of histone $\mathrm{H} 3$ and LL-37 can influence neutrophil NETosis and an increased risk of respiratory infection, respectively, are warranted.

\section{Acknowledgments}

This work has been funded, in parts, by the Higher Education Authority of Ireland, Science Foundation of Ireland through the Advanced Materials and BioEngineering Research (AMBER) project (Grant \#SFI/12/RC/2278), NANoREG project (FP7-NMP2012 Grant \#310584) and the Cornwall Arthritis Trust, UK. JM was supported by the Swiss-EU Erasmus Mobility Program. NKV was supported by Lee Kong Chian School of Medicine, Nanyang Technological University and the Ministry of Education of Singapore (StartUp-Grant and AcRF Tier 1 Grant \#2014-T1-001-141).

\section{Disclosure}

The authors report no conflicts of interest in this work.

\section{References}

1. López-Campos JL, Ruiz-Ramos M, Soriano JB. Mortality trends in chronic obstructive pulmonary disease in Europe, 1994-2010: a joinpoint regression analysis. Lancet Respir Med. 2014;2(1):54-62.

2. Blanc $P D$, Iribarren $C$, Trupin $L$, et al. Occupational exposures and the risk of COPD: dusty trades revisited. Thorax. 2009;64(1):6-12.

3. Davis RD. Cadmium in sludges used as fertilizer. Experientia Suppl. 1986;50:55-65.

4. Clarke BB, Brennan E. Tobacco leaves accumulate cadmium from root applications of the heavy metal. Tob Sci. 1983;27:28-29.

5. Mussalo-Rauhamaa H, Leppänen A, Salmela SS, Pyysalo H. Cigarettes as a source of some trace and heavy metals and pesticides in man. Arch Environ Health. 1986;41(1):49-55. 
6. Marano KM, Naufal ZS, Kathman SJ, et al. Cadmium exposure and tobacco consumption: biomarkers and risk assessment. Regul Toxicol Pharmacol. 2012;64(2):243-252.

7. Satarug S, Moore MR. Adverse health effects of chronic exposure to low-level cadmium in foodstuffs and cigarette smoke. Environ Health Perspect. 2004;112(10):1099-1103.

8. Satarug S, Garrett SH, Sens MA, Sens DA. Cadmium, environmental exposure, and health outcomes. Environ Health Perspect. 2010;118(2) $182-190$.

9. Waalkes MP. Cadmium carcinogenesis. Mutat Res. 2003;533(1-2): 107-120.

10. WHO. Cadmium. In: Guidelines for Drinking-water Quality. 3rd ed. Geneva: World Health Organization; 2008:317-319.

11. Mannino DM, Holguin F, Greves HM, Savage-Brown A, Stock AL, Jones RL. Urinary cadmium levels predict lower lung function in current and former smokers: data from the Third National Health and Nutrition Examination Survey. Thorax. 2004;59(3):194-198.

12. Friberg L. Proteinuria and kidney injury among workmen exposed to cadmium and nickel dust - preliminary report. J Ind Hyg Toxicol. 1948;30(1):32-36.

13. Bonnell JA. Emphysema and proteinuria in men casting coppercadmium alloys. Br J Ind Med. 1955;12(3):181-195.

14. Kazantzis G, Flynn FV, Spowage JS, Trott DG. Renal tubular malfunction and pulmonary emphysema in cadmium pigment workers. $Q \mathrm{JMed}$. 1963;32(126):165-192.

15. Armstrong BG, Kazantzis G. The mortality of cadmium workers Lancet. 1983;1(8339):1425-1427.

16. Davison AG, Fayers PM, Taylor AJ, et al. Cadmium fume inhalation and emphysema. Lancet. 1988;1(8587):663-667.

17. Snider GL, Hayes JA, Korthy AL, Lewis GP. Centrilobular emphysema experimentally induced by cadmium chloride aerosol. Am Rev Respir Dis. 1973;108(1):40-48.

18. Hnizdo E, Vallyathan V. Chronic obstructive pulmonary disease due to occupational exposure to silica dust: a review of epidemiological and pathological evidence. Occup Environ Med. 2003;60(4):237-243.

19. Mohamed BM, Verma NK, Davies AM, et al. Citrullination of proteins: a common post-translational modification pathway induced by different nanoparticles in vitro and in vivo. Nanomedicine (Lond). 2012 7(8):1181-1195

20. Kuo YB, Chang CA, Wu YK, et al. Identification and clinical association of anti-cytokeratin 18 autoantibody in COPD. Immunol Lett. 2010;128(2):131-136.

21. Schamberger AC, Staab-Weijnitz CA, Mise-Racek N, Eickelberg O. Cigarette smoke alters primary human bronchial epithelial cell differentiation at the air-liquid interface. Sci Rep. 2015;5:8163.

22. Schellekens GA, de Jong BA, van den Hoogen FH, van de Putte LB, van Venrooij WJ. Citrulline is an essential constituent of antigenic determinants recognized by rheumatoid arthritis-specific autoantibodies. J Clin Invest. 1998;101(1):273-281

23. Lugli EB, Correia RE, Fischer R, et al. Expression of citrulline and homocitrulline residues in the lungs of non-smokers and smokers: implications for autoimmunity in rheumatoid arthritis. Arthritis Res Ther. 2015;17:9.

24. Ruiz-Esquide V, Gomara MJ, Peinado VI, et al. Anti-citrullinated peptide antibodies in the serum of heavy smokers without rheumatoid arthritis. A differential effect of chronic obstructive pulmonary disease? Clin Rheumatol. 2012;31(7):1047-1050.

25. György B, Tóth E, Tarcsa E, Falus A, Buzás EI. Citrullination: a posttranslational modification in health and disease. Int J Biochem Cell Biol. 2006;38(10):1662-1677.

26. Makrygiannakis D, Hermansson M, Ulfgren AK, et al. Smoking increases peptidylarginine deiminase 2 enzyme expression in human lungs and increases citrullination in BAL cells. Ann Rheum Dis. 2008;67(10): 1488-1492.
27. Hobbs RP, Jacob JT, Coulombe PA. Keratins are going nuclear. Dev Cell. 2016;38(3):227-233.

28. Sigari N, Moghimi N, Shahraki FS, Mohammadi S, Roshani D. Anticyclic citrullinated peptide (CCP) antibody in patients with woodsmoke-induced chronic obstructive pulmonary disease (COPD) without rheumatoid arthritis. Rheumatol Int. 2015;35(1):85-91.

29. Wood AM, de Pablo P, Buckley CD, Ahmad A, Stockley RA. Smoke exposure as a determinant of autoantibody titre in $\alpha 1$-antitrypsin deficiency and COPD. Eur Respir J. 2011;37(1):32-38.

30. Baka Z, Barta P, Losonczy G, et al. Specific expression of PAD4 and citrullinated proteins in lung cancer is not associated with anti-CCP antibody production. Int Immunol. 2011;23(6):405-414.

31. Agustí A, MacNee W, Donaldson K, Cosio M. Hypothesis: does COPD have an autoimmune component? Thorax. 2003;58(10):832-834.

32. Hutchinson D, Shepstone L, Moots R, Lear JT, Lynch MP. Heavy cigarette smoking is strongly associated with rheumatoid arthritis (RA), particularly in patients without a family history of RA. Ann Rheum Dis. 2001;60(3):223-227.

33. Murphy D, Hutchinson D. Is male rheumatoid arthritis an occupational disease? a review. Open Rheumatol J. 2017;11(1):88-105.

34. Ungprasert P, Srivali N, Cheungpasitporn W, Davis Iii JM. Risk of incident chronic obstructive pulmonary disease in patients with rheumatoid arthritis: a systematic review and meta-analysis. Joint Bone Spine. 2016;83(3):290-294.

35. Hutchinson D. Cadmium, one of the villains behind the curtain: has exposure to cadmium helped to pull the strings of seropositive rheumatoid arthritis pathogenesis all along? Int J Rheum Dis. 2015;18(5): $570-573$.

36. Koziel J, Bryzek D, Sroka A, et al. Citrullination alters immunomodulatory function of LL-37 essential for prevention of endotoxin-induced sepsis. J Immunol. 2014;192(11):5363-5372.

37. Obermayer A, Stoiber W, Krautgartner WD, et al. New aspects on the structure of neutrophil extracellular traps from chronic obstructive pulmonary disease and in vitro generation. PLoS One. 2014;9(5): e97784.

38. Qiu SL, Zhang H, Tang QY, et al. Neutrophil extracellular traps induced by cigarette smoke activate plasmacytoid dendritic cells. Thorax. 2017;72(12):1084-1093.

39. Person RJ, Tokar EJ, Xu Y, Orihuela R, Ngalame NN, Waalkes MP. Chronic cadmium exposure in vitro induces cancer cell characteristics in human lung cells. Toxicol Appl Pharmacol. 2013;273(2):281-288.

40. Lieber M, Smith B, Szakal A, Nelson-Rees W, Todaro G. A continuous tumor-cell line from a human lung carcinoma with properties of type II alveolar epithelial cells. Int J Cancer. 1976;17(1):62-70.

41. Foster KA, Oster CG, Mayer MM, Avery ML, Audus KL. Characterization of the A549 cell line as a type II pulmonary epithelial cell model for drug metabolism. Exp Cell Res. 1998;243(2):359-366.

42. Nardone LL, Andrews SB. Cell line A549 as a model of the type II pneumocyte. Phospholipid biosynthesis from native and organometallic precursors. Biochim Biophys Acta. 1979;573(2):276-295.

43. Bicker KL, Thompson PR. The protein arginine deiminases: structure, function, inhibition, and disease. Biopolymers. 2013;99(2):155-163.

44. Szuster-Ciesielska A, Stachura A, Słotwińska M, et al. The inhibitory effect of zinc on cadmium-induced cell apoptosis and reactive oxygen species (ROS) production in cell cultures. Toxicology. 2000;145(2-3): 159-171.

45. Al-Khafaji AB, Tohme S, Yazdani HO, Miller D, Huang H, Tsung A. Superoxide induces neutrophil extracellular trap formation in a TLR-4 and NOX-dependent mechanism. Mol Med. 2016;22:621.

46. Kirkil G, Hamdi Muz M, Seçkin D, Şahin K, Küçük Ö. Antioxidant effect of zinc picolinate in patients with chronic obstructive pulmonary disease. Respir Med. 2008;102(6):840-844. 


\section{Supplementary materials}

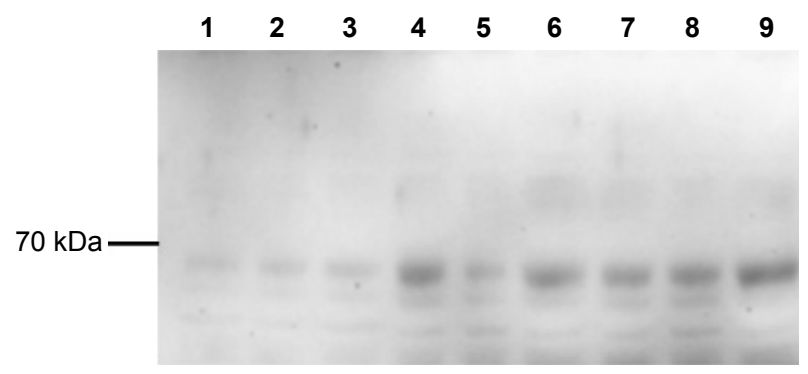

Figure SI A549 cell lysates probed for citrullinated proteins after treatment with Cd-containing materials.

Notes: Lanes, left to right, I, no treatment; 2, $\mathrm{CdCl}_{2}$; 3, CdO; 4, pre-combustion $\mathrm{CdCl}_{2}+$ ufCB; 5, pre-combustion $\mathrm{CdO}+$ ufCB; 6, post-combustion $\mathrm{CdCl}$ + ufCB; 7, postcombustion $\mathrm{CdO}+$ ufCB; 8, ufCB; 9, CdTe quantum dots.

Abbreviations: $\mathrm{Cd}$, cadmium; $\mathrm{CdO}$, cadmium oxide; $\mathrm{CdCl}_{2}$, cadmium chloridel; ufCB, ultrafine carbon black.

Table SI Identified citrullinated proteins with MS analysis scores over 100 in the immunoprecipitates of A549 cells after exposure to cadmium chloride $\left(\mathrm{CdCl}_{2}\right.$; post-combustion) and ultrafine carbon black (ufCB)

\begin{tabular}{|c|c|c|c|c|c|c|c|c|c|c|}
\hline Accession & Description & Score & Coverage & \# Proteins & $\begin{array}{l}\text { \# Unique } \\
\text { peptides }\end{array}$ & \# Peptides & \# PSMs & \# AAs & MW (kDa) & calc. pl \\
\hline \multicolumn{11}{|c|}{ Post-combustion $\mathrm{CdCl}_{2}+$ ufCB } \\
\hline H6VRG0 & Keratin I & I,888.24 & 70.50 & 4 & 56 & 62 & 646 & 644 & 65.9 & 7.80 \\
\hline P35527 & $\begin{array}{l}\text { Keratin, type I } \\
\text { cytoskeletal } 9\end{array}$ & $|, 8| 2.5 \mid$ & 80.58 & 1 & 40 & 40 & 545 & 623 & 62.0 & 5.24 \\
\hline PI3645 & $\begin{array}{l}\text { Keratin, type I } \\
\text { cytoskeletal I0 }\end{array}$ & 519.10 & 58.22 & 1 & 27 & 32 & 168 & 584 & 58.8 & 5.21 \\
\hline P35908 & $\begin{array}{l}\text { Keratin, type II cytoskeletal } \\
2 \text { epidermal }\end{array}$ & 343.55 & 61.35 & 1 & 29 & 41 & 115 & 639 & 65.4 & 8.00 \\
\hline P04259 & $\begin{array}{l}\text { Keratin, type II } \\
\text { cytoskeletal 6B }\end{array}$ & 304.03 & 54.26 & 1 & 2 & 32 & 96 & 564 & 60.0 & 8.00 \\
\hline QOIINI & Keratin 77 & 228.62 & 14.36 & 2 & 5 & 9 & 73 & 578 & 61.8 & 5.85 \\
\hline B4DRRO & $\begin{array}{l}\text { cDNA FLJ539I0, highly } \\
\text { similar to Keratin, type II } \\
\text { cytoskeletal 6A }\end{array}$ & 213.23 & 62.80 & 2 & 4 & 36 & 73 & 535 & 57.8 & 8.00 \\
\hline PI3647 & $\begin{array}{l}\text { Keratin, type II } \\
\text { cytoskeletal } 5\end{array}$ & 189.16 & 53.56 & 1 & 23 & 36 & 63 & 590 & 62.3 & 7.74 \\
\hline P02533 & $\begin{array}{l}\text { Keratin, type I } \\
\text { cytoskeletal I4 }\end{array}$ & 113.20 & 51.69 & 1 & 6 & 24 & 36 & 472 & 51.5 & 5.16 \\
\hline P08779 & $\begin{array}{l}\text { Keratin, type I } \\
\text { cytoskeletal I6 }\end{array}$ & 111.65 & 46.72 & 1 & 8 & 22 & 35 & 473 & 51.2 & 5.05 \\
\hline \multicolumn{11}{|l|}{ ufCB } \\
\hline H6VRF8 & Keratin I & $2,432.14$ & 77.33 & 3 & 59 & 66 & 813 & 644 & 66.0 & 8.12 \\
\hline P35527 & $\begin{array}{l}\text { Keratin, type I } \\
\text { cytoskeletal } 9\end{array}$ & $2,225.33$ & 82.50 & I & 48 & 48 & 627 & 623 & 62.0 & 5.24 \\
\hline PI3645 & $\begin{array}{l}\text { Keratin, type I } \\
\text { cytoskeletal } 10\end{array}$ & 778.05 & 65.07 & 1 & 31 & 37 & 243 & 584 & 58.8 & 5.21 \\
\hline P35908 & $\begin{array}{l}\text { Keratin, type II cytoskeletal } \\
2 \text { epidermal }\end{array}$ & 521.35 & 73.24 & 1 & 37 & 47 & 177 & 639 & 65.4 & 8.00 \\
\hline P04259 & $\begin{array}{l}\text { Keratin, type II } \\
\text { cytoskeletal 6B }\end{array}$ & 287.78 & 53.72 & 1 & 2 & 32 & 93 & 564 & 60.0 & 8.00 \\
\hline QOIINI & Keratin 77 & 208.62 & 19.03 & 2 & 8 & 13 & 64 & 578 & 61.8 & 5.85 \\
\hline PI3647 & $\begin{array}{l}\text { Keratin, type II } \\
\text { cytoskeletal } 5\end{array}$ & 203.56 & 53.90 & 1 & 26 & 38 & 69 & 590 & 62.3 & 7.74 \\
\hline B4DRRO & $\begin{array}{l}\text { cDNA FLJ539I0, highly } \\
\text { similar to Keratin, type II } \\
\text { cytoskeletal 6A }\end{array}$ & 188.92 & 55.89 & 3 & 4 & 32 & 64 & 535 & 57.8 & 8.00 \\
\hline
\end{tabular}


Table SI (Continued)

\begin{tabular}{|c|c|c|c|c|c|c|c|c|c|c|}
\hline Accession & Description & Score & Coverage & \# Proteins & $\begin{array}{l}\text { \# Unique } \\
\text { peptides }\end{array}$ & \# Peptides & \# PSMs & \# AAs & MW [kDa] & calc. pl \\
\hline P02533 & $\begin{array}{l}\text { Keratin, type I } \\
\text { cytoskeletal I4 }\end{array}$ & I 12.72 & 41.95 & 1 & 8 & 20 & 36 & 472 & 51.5 & 5.16 \\
\hline P08779 & $\begin{array}{l}\text { Keratin, type I } \\
\text { cytoskeletal } 16\end{array}$ & 108.85 & 42.28 & I & 7 & 20 & 37 & 473 & 51.2 & 5.05 \\
\hline B4DRWI & $\begin{array}{l}\text { cDNA FLJ55805, highly } \\
\text { similar to Keratin, type II } \\
\text { cytoskeletal } 4\end{array}$ & 101.73 & 20.46 & 4 & 6 & 10 & 32 & 474 & 51.7 & 6.81 \\
\hline
\end{tabular}

Abbreviations: $\mathrm{MS}$, mass spectrometry; $\mathrm{CdCl}_{2}$, cadmium chloridel; ufCB, ultrafine carbon black; PSM, peptide spectrum matches; $\mathrm{AA}$, amino acids; calc. pl, calculated isoelectric point.

\section{Publish your work in this journal}

The International Journal of COPD is an international, peer-reviewed journal of therapeutics and pharmacology focusing on concise rapid reporting of clinical studies and reviews in COPD. Special focus is given to the pathophysiological processes underlying the disease, intervention programs, patient focused education, and self management protocols.

\section{Dovepress}

This journal is indexed on PubMed Central, MedLine and CAS. The manuscript management system is completely online and includes a very quick and fair peer-review system, which is all easy to use. Visit http://www.dovepress.com/testimonials.php to read real quotes from published authors.

Submit your manuscript here: http://www.dovepress.com/international-journal-of-chronic-obstructive-pulmonary-disease-journal 